\title{
APLIKASI CANGKANG DAN DAGING KEONG MAS (Pomacea canaliculata L.) SEBAGAI ZAT PENGATUR TUMBUH ORGANIK TERHADAP PERTUMBUHAN TANAMAN SELADA (Lactuca sativa L.)
}

\author{
Vivin Andriani \\ Program Studi Biologi Fakultas Matematika dan Ilmu Pengetahuan Alam \\ Universitas PGRI Adi Buana Surabaya \\ Email: vivin.andriani@yahoo.com
}

\begin{abstract}
ABSTRAK
Zat pengatur tumbuh (ZPT) termasuk kedalam senyawa organik yang dapat berpengaruh terhadap proses fisiologis tumbuhan. Bahan baku yang dapat digunakan sebagai ZPT antara lain keong mas. Penelitian ini bertujuan untuk mengetahui potensi pemberian ZPT daging, cangkang serta kombinasi daging dan cangkang keong mas dalam pertumbuhan dan kandungan klorofil tanaman selada. Penelitian terdiri dari 3 perlakuan yaitu pupuk cair daging keong mas (D), pupuk cair cangkang keong mas (C) dan kombinasi daging dan cangkang keong mas (DC) dengan masing-masing konsentrasi 0\% (kontrol), 5\%, 15\% dan $25 \%$. Parameter yang diamati adalah jumlah daun, lebar daun, tinggi tanaman, dan kandungan klorofil. Hasil penelitian menunjukkan bahwa pertumbuhan tanaman selada setiap perlakuan berpengaruh signifikan pada jumlah daun, lebar daun, tinggi tanamn dan kandungan klorofil. Pemberian pupuk keong mas memberikan pertumbuhan dan hasil yang optimal pada parameter pertumbuhan adalah perlakuan DC 15\% dan kandungan klorofil adalah D $25 \%$.
\end{abstract}

Kata Kunci: ZPT, Pupuk cair, Keong mas, Pertumbuhan, Klorofil

\section{PENDAHULUAN}

Sistem pertanian sekarang ini banyak yang memanfaatkan bahan organik sebagai ZPT. Salah satu bahan organik yang mengandung hormon auksin dapat diperoleh dari limbah keong mas mampu mengatur pertumbuhan tanaman.

Keong mas selama ini dikenal sebagai hewan penggangu tanaman di lahan persawahan dan perkembangbiakan keong mas yang relatif cepat, sehingga hewan ini dapat merusak sekitar $10-40 \%$ area persawahan (Budiono, 2006).
Keong mas mengandung unsur kalsium sebesar $40 \%$, Fosfor 0,2\% (Delviat et al, 2015) serta dalam daging keong mas terdapat asam amino triftopan (Damayanti, 2015).

Kalsium berperan bagi tanaman untuk perkembangan bagian akar, daun, dan proses pembungaan (Rostini, 2011). Unsur fosfor membantu perkecambahan, perkembangan tumbuhan dan mempercepat proses pematangan pada buah (Indrasari dan Syukur, 2006). Asam amino triftopan merupak suatu pekusor 
pembentukan Indole Acetic Acid (IAA) pada tanaman (Damayanti, 2015).

\section{METODE PENELITIAN}

\section{Rancangan Percobaan}

Penelitian ini bersifat eksperimen dengan menggunakan rancangan Acak lengkap (RAL) yang terdiri dari 3 perlakuan yaitu daging keong mas (D), cangkang keong mas (C) dan kombinasi daging dan cangkang keong mas (DC) dan setiap perlakuan menggunakan 3 konsentrasi yaitu $5 \%, 15 \%$ dan $25 \%$ dan $0 \%$ sebagai kontrol.

\section{Prosedur Pelaksanaan}

Pembuatan fermentasi cangkang dan daging Keong mas

Keong mas direbus dan pisahkan cangkang dan dagingnya. Campurkan $1 \mathrm{~kg}$ cangkang/daging keonng mas yang sudah ditumbuk dengan $500 \mathrm{ml}$ molase, 4 liter air cucian beras dan $160 \mathrm{ml}$ EM4.
Fermentasi dilakuakan selama 14 hari.

\section{Tahap Pelaksanaan}

Pemberian ZPT dilakukan 2 kali dalam satu minggu sekali pada sore hari dengan volume penyemprotan $100 \mathrm{ml}$ untuk setiap tanaman dan dilakukan setelah tanaman selada derdaun tiga.

\section{Pengambilan Data}

Data yang diambil berupa data pertumbuhan (jumlah daun, lebar daun, tinggi tanaman) dan kandungan klorofil tanaman selada 4 minggu setelah tanam (MST).

Penentuan kandungan klorofil dilakukan pada minggu ke empat setelah dilakukan perlakuan. Kandungan klorofil diukur menggunakan spektrofotometri.

\section{Analisis Data}

Analisis data menggunakan one way satu arah yang dibantu dengan aplikasi SPSS.

\section{HASIL PENELITIAN}

\section{Jumlah Daun}

Hasil pengukuran jumlah daun tanaman selada selama 4 minggu setelah tanam (MST). 


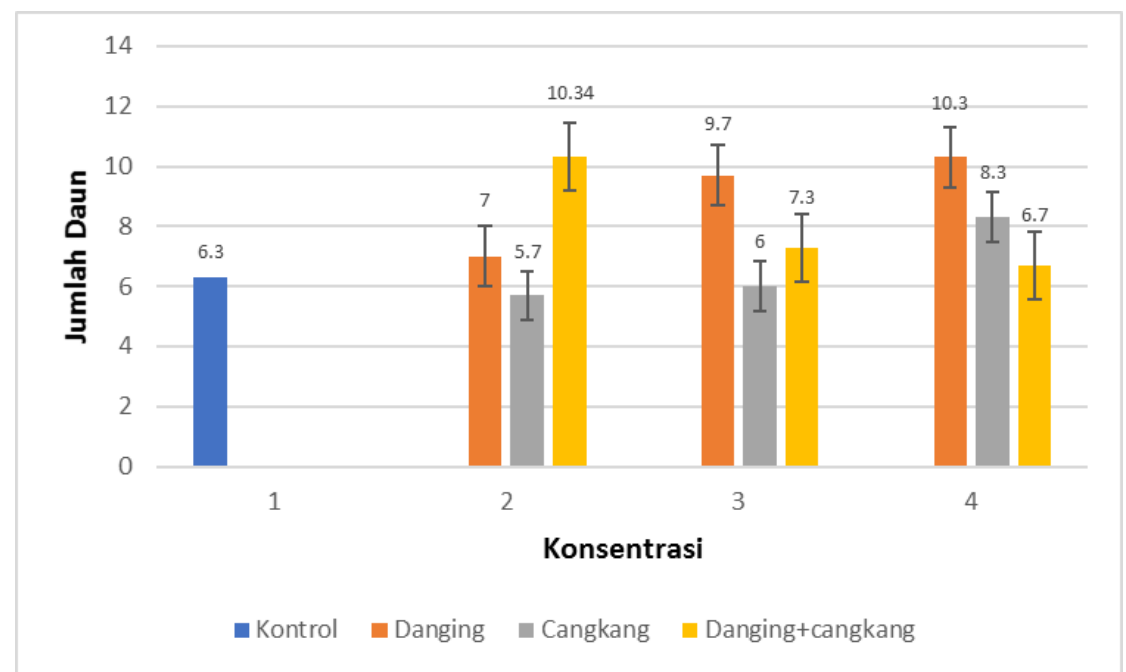

Gambar 1 Grafik Jumlah Daun Tanaman Selada 4 MST

Berdasarkan gambar 1 sedangkan jumlah daun terendah menunjukkan bahwa jumlah daun pada perlakuan ZPT yang berasal tanaman selada tertinggi pada dari cangkang keong mas dengan perlakuan ZPT yang berasal dari konsentrasi 5\% dengan rata-rata cangkang keong mas dengan konsentrasi $25 \%$ dan perlakuan ZPT kombinasi dari daging dan cangkang keong mas pada taraf konsentrasi $5 \%$ dengan rata-rata jumlah daun 9,7 helai daun, jumlah daun 5,7 helai.

\section{Lebar Daun}

Hasil pengukuran lebar daun tanaman selada selama 4 minggu setelah tanam (MST).

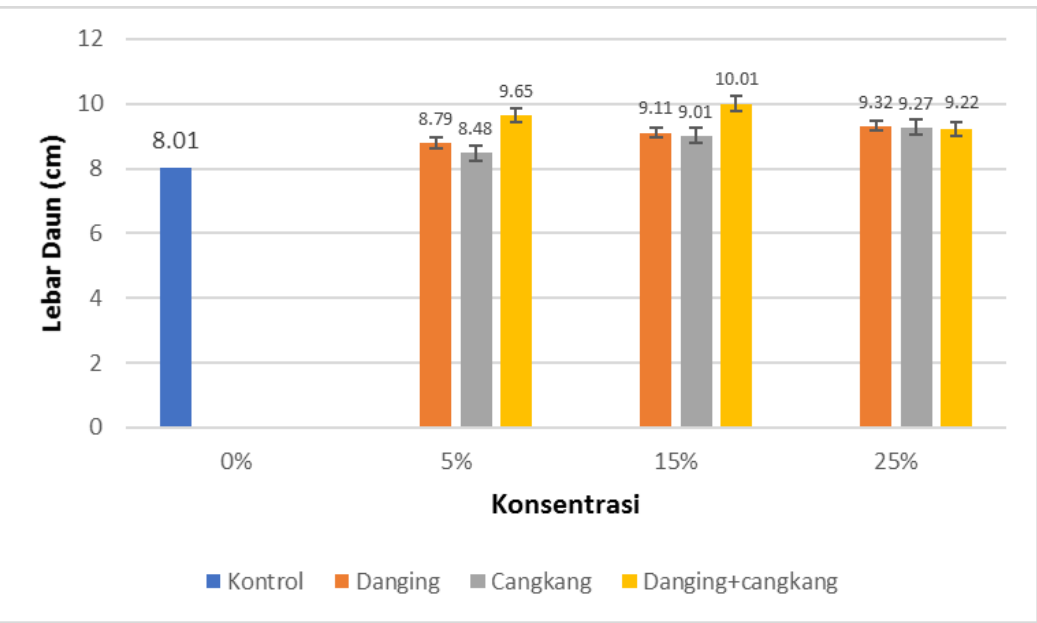

Gambar 2 Grafik Lebar Daun Tanaman Selada 4 MST 
Berdasarkan gambar 2 dari cangkang keong mas dengan menunjukkan bahwa lebar daun konsentrasi 5\% dengan rata-rata tanaman selada tertinggi pada lebar daun $8,48 \mathrm{~cm}$.

perlakuan ZPT yang berasal dari kombinasi daging dan cangkang keong mas pada konsentrasi $15 \%$ dengan rata-rata lebar daun 10,01 $\mathrm{cm}$, sedangkan lebar daun terkecil pada perlakuan ZPT yang berasal

\section{Tinggi Tanaman}

Hasil pengukuran tinggi tanaman selada selama 4 minggu setelah tanam (MST).

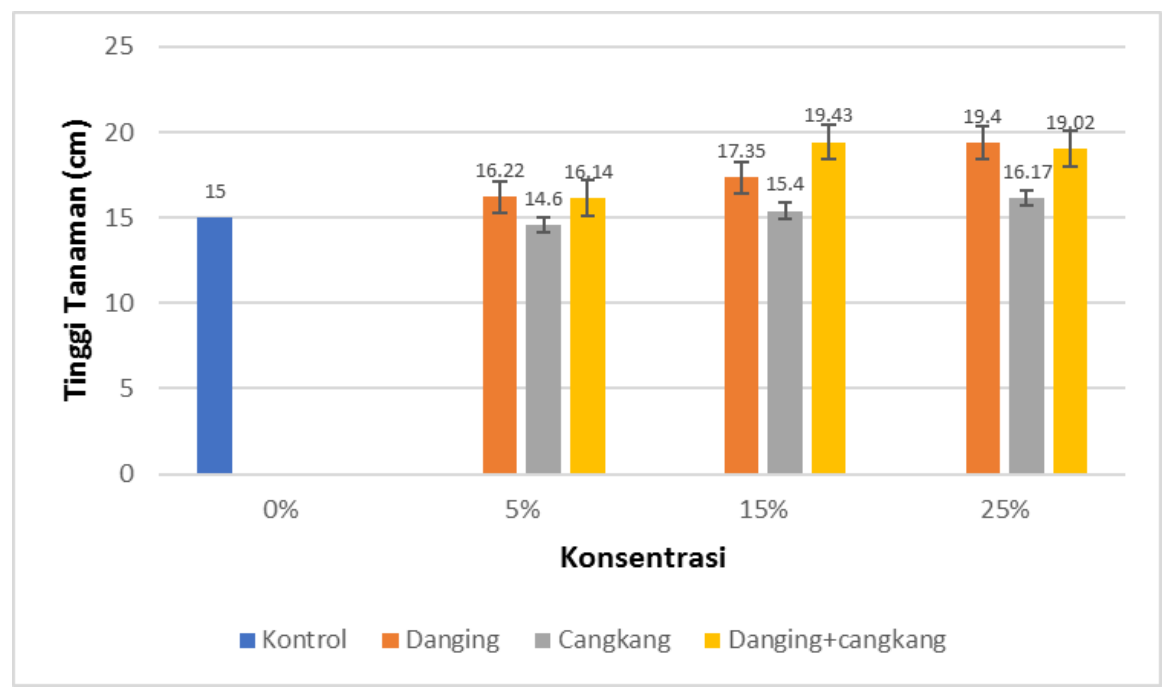

Gambar 3 Grafik Tinggi Tanaman Selada 4 MST

Berdasarkan gambar 3 terendah dengan konsentrasi 5\% menunjukkan bahwa tinggi tanaman selada tertinggi pada perlakuan ZPT yang berasal dari kombinasi daging dan cangkang keong mas pada konsentrasi $15 \%$ dengan rata-rata tinggi tanaman 19,43 $\mathrm{cm}$, sedangkan pada perlakuan ZPT dengan rata-rata tinggi tanaman $14,60 \mathrm{~cm}$.

yang berasal dari cangkang keong

\section{Kandungan Klorofil}

Hasil pengukuran kandungan klorofil daun selada selama 4 minggu setelah tanam (MST). 


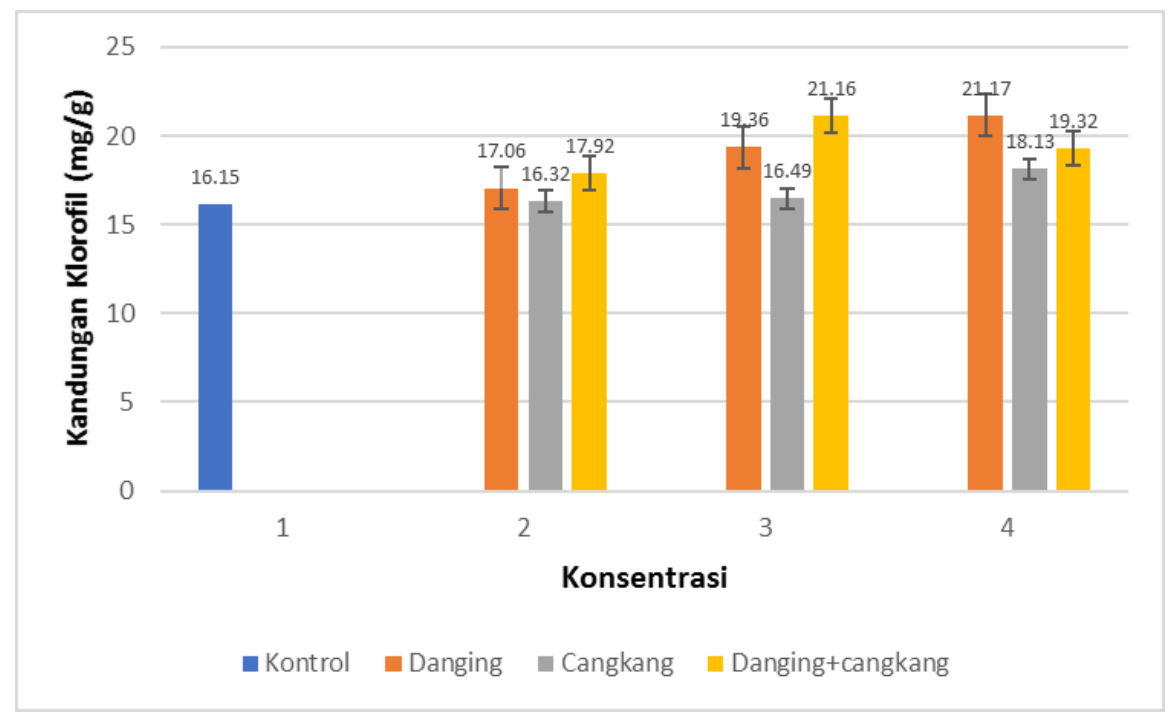

Gambar 4 Kadar Klorofil Daun Selada 4 MST

Berdasarkan gambar 4 menunjukkan bahwa kandungan klorofil daun selada tertinggi pada perlakuan ZPT yang berasal dari daging serta kombinasi daging dan cangkang keong mas pada konsentrasi $15 \%$ dengan rata-rata tinggi tanaman $10,3 \mathrm{mg} / \mathrm{g}$, sedangkankandungan klorofil tanaman terendah pada perlakuan ZPT yang berasal dari cangkang keong mas dengan konsentrasi 5\% dengan rata-rata kadar klorofil daun selada $5,7 \mathrm{mg} / \mathrm{g}$.

\section{PEMBAHASAN}

Hasil penelitian ini menunjukan bahwa pemberian ZPT keong mas yang telah terfermentasi dengan EM4 meningkatkan pertumbuhan dan kandungan klorofil pada tanaman selada dapat dikarenakan mikroorganisme yang terdapat pada EM4 meningkatkan kelarutan mineral yang terdapat pada keong mas.

\section{Bakteri} asam

laktat (Lactobacillus menekan sp.) berperan pertumbuhan mikroorganisme yang merugikan dan dapat meningkatkan percepatan perombakan bahan-bahan organik (Indriani, 2011). Saccharomyces $s p$. berperanmenghasilkan zat-zat bioaktif seperti hormon dan enzim yang berfungsi meningkatkan jumlah sel aktif dan perkembangan akar (Namang, 2015). Bakteri fotosintetik (Rhodopseudomonas $s p$.) berperan mengeluarkan senyawa-senyawa nitrogen (asam amino) yang dikeluarkan bakteri fotosintetik yang berguna sebagai substrat (Namang, 2015). Actinomycetessp. Berperan menghasilkan zat-zat anti mikroba yang dapat menekan pertumbuhan jamur dan bakteri (Indriani, 2011). 
Nitogen berperan penting dalam proses pembentukan klorofil yang digunakan dalam fotosintesis. Proses fotosintesis pada tanaman berfungsi dalam memperoleh nutrisi dan energy, sedangkan kandungan klorofil yang cukup dapat memecu pertumbuhan tanaman terutama pertumbuhan organ vegetative (Purwadi, 2011).

Pertumbuhan jumlah daun, lebar daun dan jumlah daun pada selada tumbuh dengan subur, hal tersebut membuktikan bahwa persediaan nitrat mencukupi kebutuhan tanaman, sehingga fotosisntesis berjalan optimal.

Fosfor pada keong mas dalam bentuk fosfat organik. Tanaman tidak akan memanfaatkan fosfat organik secara langsung, sehingga adanya proses mineralisasi untuk dapat diserap tanaman (Rosmarkam and Yuwono, 2002). Dalam proses fermentasi pupuk organik akan mengalami proses mineralisasi menjadi fosfat anorganik. Proses mineralisasi ini dapat terjadi dengan adanya bantuan mikroba pelarut fosfat yang berada pada EM4 (Efefective Microorganisme) yang digunakan dalam proses fermentasi. Pada proses fermentasi terjadinya pelarutan fosfat secara mekanisme biologi oleh mikroba pelarut fosfat dengan memproduksi enzim fosfatase. Enzi mini bekerja dengan memutus ikatan fosfat dari senyawa organik pengikatnya sehingga menjadi bentuk yang dapat dimanfaatkan tumbuhan (Fitriatin et all., 2009).

Kalium diserap oleh tumbuhan dalam bentuk $\mathrm{K}^{+}$. unsur ini terdapat dalam sel penjaga yang berperan dalam menutup dan membukanya stomata. Terbukanya stomata terjadi apabila sel penjaga memiliki kandungan kalium yang cukup, karbohidrat akan ditangkap saat stomata terbuka. Karbohidrat merupakan komponen yang sangat dibutuhkan dalam proses fotosintesis (Murschner, 2012).

Pada ikatan koloid di tanah $\mathrm{Ca}$ dibebaskan oleh ion $2 \mathrm{H}^{+}$. unsur $\mathrm{Ca}^{++}$dalam tanah dapat menjadi 10 kali lipat atau lebih tinggi daripada $\mathrm{K}^{+}$, tetapi penyerapan $\mathrm{K}^{+}$oleh akar tanaman lebih tinggi daripada $\mathrm{Ca}^{++}$. Penyerapan $\mathrm{Ca}$ ditekan oleh adanya $\mathrm{K}^{+}$dan $\mathrm{NH}_{4}^{+}$yang lebih cepat diserap oleh akar (Castan et al., 2016).

Asam amino aromatik triptofan masuk dalam jalur utama dari biosintesis IAA. Triptofan terbentuk dari PEP (Forfor enol piruvat) dan eritrosa-4-fosfat. Jalur biosintesis IAA dari PEP sampai triptofan merupakan jalur biosintesis dari senyawa-senyawa fenolik. IAA dapat dibentuk secara langsung oleh asam serine dengan indol. Pembentukan asam amino triptofan berguna dalam pembuatan protein-protein sel. Triptofan akan mengalami dekarboksilasi menjadi tryptamine yang kemudian 
teroksidasi dan deaminasi untuk indoleacetaldehyde. Molekul tersebut akan dioksidasi menghasilkan asam indole acetic (Davies, 1995).

\section{SIMPULAN}

Berdasarkan penelitian yang telah pemberian ZPT keong mas berpengaruh signifikan pada parameter pertumbuhan dan kadar klorofil tanaman selada dan pemberian pupuk keong mas memberikan pertumbuhan dan hasil yang optimal pada parameter pertumbuhan adalah perlakuan DC $15 \%$ dan kandungan klorofil adalah D $25 \%$.

\section{UCAPAN TERIMA KASIH}

Penulis mengucapkan terima kasih kepada LPPM Unipa Surabaya yang telah memberikan dukungan finansial terhadap penelitian ini.

\section{DAFTAR PUSTAKA}

Budiono, S. 2006. Teknik Mengendalikan Keong Mas Pada Tanaman Padi. Jurnal Ilmu-Ilmu Pertanian 2(2): 128-133.

Castan E, Satti P, González-Polo M, Iglesias MC, Mazzarino MJ. 2016. Managing the value of composts as organic amendments and fertilizers in sandy soils. Agriculture, Ecosystems and Environment. 224: 29-38.
Damayanti, F.F. 2015. Pngaruh Konsntrasi Mikroorganism Lokal (MOL) Berbahan Dasar Keong Mas (Pomaca canaliculate L.) Terhadap Pertumbuhan Tanaman Cabai Keriting. Skripsi: Universitas Sanata Dharma.

Davies, J.P. 1995. Plant hormone: their nature, occurrence and function. In: P.J. Davies (ed.): Plant Hormones: Phisiology, Biochemistry, and Moleculer Biology. Boston: Kluwer Academic Publisher.

Delvita, H. 2015. Pengaruh Variasi Temperatur Kalsinasi Terhadap Karakteristik Kalsium Karbonat $\left(\mathrm{CaCO}_{3}\right)$ dalam Cangkang Keong Sawah (Pila ampullaceal) Yang Terdapat di Kabupaten Pasaman. Jurnal Pillar Of Physics. Vol. 6: 17-24.

Indriani, Y. H. 2011. Membuat Kompos Secara Kilat. Penebar Swadaya. Yogyakarta.

Indrasari, A. dan A. Syukur. 2006. Pengaruh Pemberian Pupuk Kandang dan Unsur Hara Mikro Terhadap Pertumbuhan Jagung Pada Ultisol yang Dikapur. Jurnal Ilmu Tanah dan Lingkungan 6(2):116-238.

Marschner, P. 2012. Mineral Nutrition of Higher Plants 
Third Edition. Elsevier Ltd. Purwadi, E. 2011. Batas Krisis

Oxford.

Namang, C. 2015. Pengaruh Pemberian

Konsentrasi EM4 yang

Berbeda-beda Terhadap

Pertumbuhan Cabai Rawit

(Capsicum frutescens L.).

Skripsi. Program Studi

Pendidikan Bilogi. Yogyakarta.

Universitas Sanata Dharma

Yogyakarta.
Suatau Unsur N dan

pengukuran Kandungan pada Tanaman. Dikutip dari: URL:/masbied.com.

Rostini, N. 2011. Enam Jurus Bertanam Cabai Bebas Hama dan Penyakit. Agromedia. Jakarta. 